\title{
RESEARCH PAPER \\ Factors that influence the price of cattle in livestock auctions: the case of the stockyard of Melipilla (Chile)
}

\author{
Javier L. Troncoso ${ }^{1}$, Alejandra Engler ${ }^{1}$, Paula Manriquez ${ }^{1}$, and Antonio Valdivia ${ }^{2}$ \\ 'Departamento de Economía Agraria, Facultad de Ciencias Agrarias, Universidad de Talca, Casilla 747 \\ Talca, Chile. \\ ${ }^{2}$ Escuela de Agronomía, Facultad de Ciencias Agrarias, Universidad de Talca, Casilla 747 Talca, Chile.
}

\begin{abstract}
J.L. Troncoso, A. Engler, P. Manríquez, and A. Valdivia. 2012. Factors that influence the price of cattle in livestock auctions: the case of the stockyard of Melipilla (Chile). Cien. Inv. Agr. 39(1): 37-45. This study aims to weigh the influence of observable traits on live cattle prices, i.e., the percent impact on the final price of various physical characteristics. These characteristics are those that commonly are published in auction catalogues, as is the case of: average lot weight, lot size, age, breed and corporal condition. In addition, the influence of seasonality and business cycles were also explored. Using the data collected from the records of El Tattersall S.A., a hedonic price function was fitted. The results showed that the most influential variables with respect to the price of beef cattle, in decreasing order, are as follows: 'condition', 'breed', 'quarter of sale' and 'year', which are followed far behind by 'lot size' and 'average weight'. The market pays a premium for Red Friesians, Crossbreds and Herefords and punishes the price of Holstein Friesians. Additionally, higher prices are paid in the last two quarters of the year than in the first two, and the third quarter is preferable to the fourth. Finally, the average lot weight and lot size are variables that have a positive, but small, influence on the price of cattle.
\end{abstract}

Key words: Hedonic price functions, marginal price, percent impact on price.

\section{Introduction}

When cattle are put to auction, their price is determined by a series of physical observable traits that in the expert eye of cattle traders, lend value to the carcass that will be produced. Although the value of live cattle is ultimately determined by the retail price of the various cuts of meat it will produce, the buyer at the stockyard can only base his purchase decision on the correlation he

Received November 8, 2010. Accepted November 18, 2011. Corresponding author: jtronc@utalca.cl believes to exist between observable traits in live cattle and meat quality. Thus, several studies have shown that observable characteristics, such as weight, breed, haircoat color, sex, muscle score, frame score, horn status, fill, corporal condition, health, body weight, lot size and management practices, affect feeder cattle prices in the market (Halfman et al., 2009; Bulut and Lawrence, 2007; Barham and Troxel, 2007; Troxel and Barham, 2007; Jones et al., 1978; Fielder and Martinez, 1974). Seasonality also has an influence as cattlemen organize their business in accordance with forage cycles. Thus, in the months of the year 
when grass is abundant, the demand for calves and yearlings is high relative to supply, and vice versa. As a consequence, feeder cattle prices tend to increase in the months of abundance and to decrease when there is a shortage of forage (Correia de Sousa, 2005).

Estimation of market values based on commodity attributes can be carried out through the estimation of a hedonic price function. A 'hedonic price function' relates the price of a commodity to its attributes or characteristics. The theoretical foundations of hedonic price functions were provided by Rosen (1974), who posited that competitive markets define implicit prices for the embodied commodity attributes and that buyers evaluate these attributes when making a purchase decision. Hedonic functions have been widely used by researchers to determine the factors that influence the price of agricultural commodities, such as wine (e.g., Combris et al., 2000; Melo et al., 2005; Nerlove, 1995; Oczkowski, 1994; Schamel and Anderson, 2001, Troncoso and Aguirre, 2006), wheat (e.g., Ahmandi-Esfahani and Stanmore, 1997), milk (Buccola and Iizuka, 1997) and cattle (Coatney et al.,1996; Lin and Mori, 1991; Wahl et al., 1995; Donnell, 2007). No such studies were found for cattle in the Chilean market.

This study aims to weigh the influence of observable traits on live cattle prices, i.e., the percent impact of various physical characteristics on the final price. These characteristics are those that are commonly published in auction catalogues, as is the case of: average lot weight, lot size, age, breed and corporal condition. In addition, the influence of seasonality and business cycles are also explored.

\section{Materials and methods}

The data for this study were obtained from the records of El Tattersall S.A, and correspond to the auctions and private sales of cattle carried out in the county of Melipilla (Chile) in the years 2006 through 2008. The dataset comprised a total of 1,420 transactions, which included 8,278 head of cattle sold with different weights, sex, breeds and corporal conditions.

Following the general hedonic functions model, it was assumed that the price of cattle is a function of the value attributed by economic agents to the visible characteristics listed in auction catalogues and specified above. It was also assumed that the market is in equilibrium, that is, all buyers have made utility-maximizing choices, given their budget constraints and knowledge of the prices and characteristics of alternative goods. Moreover, all firms have made profit-maximizing decisions that take into account their production costs and that the resulting prices and quantities have been set at market-clearing levels (Rosen, 1974). Because the predominant price-setting system in the Chilean cattle market is the ascending bid auction carried out in a transparent manner and allowing free entry of sellers and buyers, this market can be deemed competitive, and the above assumptions can be assumed to be realistic.

The variables employed in the model were limited by the data available in the records of El Tattersal S.A., which are: date of transaction, animal types, lot size, average body weight and age of the lot, breed, sex, corporal condition and average price. Notably, all of these variables have been used in the studies cited above and, hence, can be considered relevant explanatory variables. They also fulfill the condition of being 'observable', which is a necessary condition for hedonic price analysis.

Three models were estimated, each for the following types of cattle: 'finished steers', 'finished heifers' and 'finished cows'. Ordinary least squares (OLS) analysis was initially employed for these estimations, but the models showed non-normality of residuals and heteroskedasticity, thus violating basic assumptions of linear regression models and barring the application of the usual parameter tests. To overcome this difficulty, robust estimations were carried out using 
the statistical software Stata 10 (Data Analysis and Statistical Software, Base Reference Manual. 2009. STATA Press, United States). Because of the ease in interpretation, a log-linear specification was adopted for all models. In summary, the following price function was estimated:

$\operatorname{Ln} P_{c}=\beta_{0}+\Sigma_{j} \beta_{j} Z_{j}+\Sigma_{w} \beta_{w} Z_{w}$

where $\mathrm{P}_{c}$ is the per-kilogram price of the c-th type of cattle (finished steers, finished heifers and finished cows), and $Z_{j}$ and $Z_{w}$ represent the $j$-th continuous variable and the $\mathrm{w}$-th binary variable, respectively.

The continuous variables used were as follows:

- $\quad$ Average lot weight, in kilograms (Weight).

- $\quad$ Lot size, in head (Head).

- $\quad$ Age, in years (Age).

And the binary variables were as follows:

- Breed, including Red Friesians (Reds), Holstein Friesians (HFriesians), Crossbreds (Cross) and Herefords (Hereford).

- Corporal condition (Condition), which indicates the fulfillment of the standard of fatness required by the market, for each breed and type of animal. Cattle traders hold very definite concepts regarding the final weight an animal should have to supply good-quality meat at slaughter, and they bid according to these concepts. When animals reach their final weight, they are referred to as 'heavy' or 'finished'.

- Season of the year, measured in quarters (Quarter Q).

- Year: Because the data belong to the years 2006 through 2008, it was considered necessary to include this variable to isolate the influence of business cycles or, as it is usually referred to in the cattle market, the 'cattle cycle' (Year AA).

To avoid collinearity between the binary variables (the so-called 'dummy variable trap') (Gujarati, 2004), a reference variable was omitted for each group of binary variables. These omitted variables were the Hereford breed, the year 2006, the fourth quarter and the type of animal used as replacement for each production process (e.g., 'lean heifers', in the case of 'finished heifers'). Hence, the results should be interpreted as departures from the price that the input type of Hereford animal obtained in the fourth quarter of 2006. This price is used as the "reference price" (RP). All prices were expressed in Chilean pesos as of July 2008 (Ch\$) using the Consumer Price Index of the Instituto Nacional de Estadísticas as deflator.

The percent impact (PI) of a variable is the percentage variation on price that can be attributed to a one-unit variation in that variable. Mathematically, this is equivalent to the following equation:

$\mathrm{PI}=100 *(\partial \mathrm{P} / \partial \mathrm{Z})(1 / \mathrm{P})$

Measurement of the percent impact on price varies with the type of variable being analyzed. As Halvorsen and Palmquist (1980) and Gujarati (2004) point out, in log-linear functions the coefficient of a continuous variable is a derivative and hence, when multiplied by 100 , it can correctly be interpreted as the percentage variation of the dependent variable in relation to a small change of the variable in question. Thus, the PI values of 'weight', 'lot size' and 'age' were calculated as $100 * \beta_{j}$ and were interpreted as the percentage change in price with respect to a one-unit variation in each variable. This method cannot be applied to binary variables, as their dichotomous form precludes interpreting the coefficients as derivatives. The percentage impact of a binary variable was estimated as follows:

$100 *\left[\exp \left(\beta_{w}-0.5 \operatorname{var}\left(\beta_{w}\right)\right)-1\right]$

which, as Kennedy (1981) has shown, is the appropriate interpretation of the coefficient of a dummy variable.

The marginal price of a variable is simply the expression of the corresponding PI in monetary terms. Once PIs have been estimated, the marginal 
price of the $\mathrm{i}$-th variable $\left(\mathrm{MP}_{\mathrm{i}}\right)$ can be estimated as follows:

$\mathrm{MP}_{\mathrm{i}}=\mathrm{PI}_{\mathrm{i}} * \mathrm{RP}_{\mathrm{c}}$

where $\mathrm{RP}_{\mathrm{c}}$ is the reference price of the $\mathrm{c}$-th type of cattle.

\section{Results and discussion}

\section{Summary statistics}

Table 1 reveals that $75 \%$ of the cattle sold correspond to 'finished' cattle, i.e., animals ready for slaughter. In this group, the most important category is steers $(57 \%)$, which is logical because the only purpose for rearing male bovines is meat production. Finished females (finished heifers and finished cows) represent much smaller percentages of the cattle sold (15 and 3\% respectively), as these animals are reared for reproduction and milk production, and only those animals that have been discarded from these functions enter the fattening process. The remaining categories are also in small numbers, reflecting the fact that replacement animals are usually bought in regions other than Melipilla, most of which are located in the southern provinces of the country.

Transactions are distributed quite evenly throughout the year, although a slight increase is noticeable in the third quarter. However it is apparent that

Table 1. Transactions classified by corporal condition and sex.

\begin{tabular}{lccccc}
\hline & \multicolumn{2}{c}{ Head } & & \multicolumn{2}{c}{ Transactions } \\
\cline { 2 - 3 } \cline { 5 - 6 } \cline { 5 - 6 } Finished steers & Number & $\%$ & & Number & $\%$ \\
Finished heifers & 4,730 & 57 & & 639 & 45 \\
Finished cows & 1,218 & 15 & & 224 & 16 \\
Lean steers & 256 & 3 & & 188 & 13 \\
Lean heifers & 1,417 & 17 & & 176 & 12 \\
Lean cows & 435 & 5 & & 101 & 7 \\
Totals & 222 & 3 & & 92 & 6 \\
\hline
\end{tabular}

the lots sold in the first two quarters of the year are smaller than those sold in the last two. As Table 2 shows, $47 \%$ and $29 \%$ of the cattle head are sold in the third and fourth quarters of the year. By comparison to the southern provinces of the country, the region of Melipilla is characterized by higher temperatures, which favor the growth of grass earlier than in the south. Also, because the climate is milder and the soils are deep and close to a neutral $\mathrm{pH}$, lucerne and other noble grass species grow very well in the region. The commercial strategy of cattle producers in Melipilla county is to fatten their cattle earlier than other competing regions and bring them to market when finished cattle are still scarce and prices are high, i.e., in the third quarter and, to a lesser extent, the fourth quarter of the year. Prices fall considerably in the first quarter (summer), when the south becomes a major supplier of beef cattle, and hence, it is a less favorable time to reach the market.

Table 2. Transactions classified by quarters of the year.

\begin{tabular}{lccccc}
\hline & \multicolumn{2}{c}{ Head } & & \multicolumn{2}{c}{ Transactions } \\
\cline { 2 - 3 } \cline { 5 - 6 } Quarters & Number & $\%$ & & Number & $\%$ \\
\hline First & 1,006 & 12 & & 353 & 25 \\
Second & 1,056 & 13 & & 373 & 26 \\
Third & 3,853 & 47 & & 409 & 29 \\
Fourth & 2,363 & 29 & & 285 & 20 \\
Totals & 8,278 & 100 & & 1,420 & 100 \\
\hline
\end{tabular}

\section{Reference prices}

Table 3 presents the reference prices used in this study. As mentioned earlier, the animals of reference are, in all cases, Herefords purchased in the $4^{\text {th }}$ quarter of the year 2006 as replacements for each type of animal, e.g., lean steers for finished steers, or lean heifers for finished heifers, etc.

Note in Table 3 that a lean Hereford cow is more highly priced than the other two types of animals. This shows the preference of cattlemen for thin mature animals, which properly fed, will show above-normal daily gains as a result of the socalled 'compensatory growth' (Fox et al., 1972). 
The hedonic price function

Table 4 presents the robust estimates for the hedonic price function for the four types of cattle under analysis. The goodness-of-fit of these equations, reflected in the corresponding R-squared values, are reasonably good, with the exception of the equation for 'Finished cows', which shows a low value. However, the overall significance of the coefficients measured by the F-statistic is high, which is confirmed by the high number of significant t-Student statistics. Examining each equation individually, very few coefficients are found to be non-significant at the usual probability levels. Hence, the equations of Table 4 can be considered valid from a statistical standpoint.

Table 3. Reference price for the different types of cattle analyzed.

\begin{tabular}{|c|c|c|c|}
\hline & \multicolumn{3}{|c|}{ Types of cattle } \\
\hline & Finished steers & Finished heifers & Finished cows \\
\hline Animal of reference & $\begin{array}{l}\text { Lean Hereford steers bought in } \\
\text { the } 4^{\text {th }} \text { Quarter of } 2006\end{array}$ & $\begin{array}{c}\text { Lean Hereford heifers bought in } \\
\text { the } 4^{\text {th }} \text { Quarter of } 2006\end{array}$ & $\begin{array}{l}\text { Lean Hereford cows bought in } \\
\text { the } 4^{\text {th }} \text { Quarter of } 2006\end{array}$ \\
\hline Average price $\left(\$ \mathrm{~kg}^{-1}\right)$ & 581 & 540 & 609 \\
\hline Average weight (kg) & 279 & 265 & 295 \\
\hline
\end{tabular}

Table 4. Hedonic price function (coefficients, t-Student statistic and significance).

\begin{tabular}{|c|c|c|c|c|c|c|}
\hline & \multicolumn{2}{|c|}{ Finished steers } & \multicolumn{2}{|c|}{ Finished heifers } & \multicolumn{2}{|c|}{ Finished cows } \\
\hline & $\begin{array}{c}\beta \\
\text { (t-Student) }\end{array}$ & Signf & $\begin{array}{c}\beta \\
\text { (t-Student) }\end{array}$ & Signf & $\begin{array}{c}\beta \\
\text { (t-Student) }\end{array}$ & Signf \\
\hline Constant & $\begin{array}{l}6.27674 \\
(283.42)\end{array}$ & $* * *$ & $\begin{array}{l}6.04883 \\
(135.0)\end{array}$ & $* * *$ & $\begin{array}{c}5.88843 \\
(61.91)\end{array}$ & $* * *$ \\
\hline Head & $\begin{array}{c}0.00093 \\
(4.19)\end{array}$ & $* * *$ & $\begin{array}{c}0.00197 \\
(3.31)\end{array}$ & $* * *$ & $\begin{array}{c}0.00619 \\
(0.91)\end{array}$ & n.s. \\
\hline Weight & $\begin{array}{c}0.00054 \\
(9.35)\end{array}$ & $* * *$ & $\begin{array}{c}0.00060 \\
(3.67)\end{array}$ & $* * *$ & $\begin{array}{c}0.00006 \\
(0.41)\end{array}$ & n.s. \\
\hline Condition & $\begin{array}{c}0.10334 \\
(10.47)\end{array}$ & $* * *$ & $\begin{array}{c}0.15591 \\
(7.58)\end{array}$ & $* * *$ & $\begin{array}{c}0.19783 \\
(7.44)\end{array}$ & $* * *$ \\
\hline Year 07 & $\begin{array}{c}-0.05372 \\
(-7.72)\end{array}$ & $* * *$ & $\begin{array}{c}0.01288 \\
(0.77)\end{array}$ & n.s. & $\begin{array}{c}0.06514 \\
(2.22)\end{array}$ & $* * *$ \\
\hline Year 08 & $\begin{array}{c}0.06670 \\
(7.63)\end{array}$ & $* * *$ & $\begin{array}{c}0.11533 \\
(5.67)\end{array}$ & $* * *$ & $\begin{array}{c}0.10725 \\
(4.39)\end{array}$ & $* * *$ \\
\hline Quarter 1 & $\begin{array}{c}-0.10154 \\
(-10.36)\end{array}$ & $* * *$ & $\begin{array}{c}-0.09487 \\
(-4.07)\end{array}$ & $* * *$ & $\begin{array}{c}-0.10468 \\
(-2.95)\end{array}$ & $* * *$ \\
\hline Quarter 2 & $\begin{array}{c}-0.06733 \\
(-7.68)\end{array}$ & $* * *$ & $\begin{array}{c}-0.11018 \\
(-5.58)\end{array}$ & $* * *$ & $\begin{array}{c}-0.11984 \\
(-3.37)\end{array}$ & $* * *$ \\
\hline Quarter 3 & $\begin{array}{c}0.01192 \\
(1.25)\end{array}$ & n.s. & $\begin{array}{c}0.05630 \\
(2.59)\end{array}$ & $* * *$ & $\begin{array}{c}0.07622 \\
(2.10)\end{array}$ & $* * *$ \\
\hline Reds & $\begin{array}{c}0.03632 \\
(4.29)\end{array}$ & $* * *$ & $\begin{array}{c}0.04998 \\
(2.16)\end{array}$ & $* * *$ & $\begin{array}{c}0.00457 \\
(0.14)\end{array}$ & n.s. \\
\hline HFriesians & $\begin{array}{c}-0.15736 \\
(-8.40)\end{array}$ & $* * *$ & $\begin{array}{c}-0.39526 \\
(-1.85)\end{array}$ & $*$ & $\begin{array}{c}-0.23177 \\
(-3.84)\end{array}$ & $* * *$ \\
\hline Crossbreds & $\begin{array}{c}0.00819 \\
(0.96)\end{array}$ & n.s. & $\begin{array}{c}0.04053 \\
(1.87)\end{array}$ & $*$ & $\begin{array}{c}0.02491 \\
(0.79)\end{array}$ & n.s. \\
\hline
\end{tabular}

$* * *=$ significant at the $1 \%$ level; $* *=$ significant at the $5 \%$ level; $*=$ significant at the $10 \%$ level; n.s. $=$ non-significant.

Observations: $\quad 812 \quad 325 \quad 279$

F: $\quad 80.62$

R-squared: $\quad 0.58$

Root MSE: $\quad 0.08$

$0.12 \quad 0.17$ 
Percent impact and marginal prices of cattle attributes

Table 5 shows the percent impact and marginal prices of the attributes of cattle under analysis in this study.

The results show that the most influential variables are, in decreasing order, 'condition', 'breed', 'quarter of sale' and 'year', which are followed far behind by 'average weight' and 'lot size'.

The process of meeting the standard of fatness is associated with marginal prices that vary between $\mathrm{Ch} \$ 133.05$ and $\mathrm{Ch} \$ 63.23$ per live kilogram, depending on the type of animal. Expressed in terms of percentages, the impact on price varies from $21.83 \%$, for 'finished cows', to $10.88 \%$, for 'finished steers'. This is in line with the findings of Barham and Troxel (2007), who reported higher prices for animals with an 'average condition' compared to thinner animals of the same type, in a study on livestock auctions in Arkansas.

Regarding breed, fattening Holstein Friesian cattle is punished by the market with a price reduction that varies between $34.17 \%$, for 'finished heifers', to $14.58 \%$, for 'finished steers'. This result is in agreement with the conclusions of Coatney et al.
(1996), who found that Holsteins are subject to price reductions with respect to English breeds. Holstein Friesians are animals that are specialized in dairy production and do not exhibit the muscular structure of beef cattle, as is the case for Herefords, Red Friesians and Crossbreds, and the market recognize this fact. Also, because Holsteins are usually taller than the aforementioned animals, it is more costly to feed them to reach the desired fatness condition, so stockmen reduce their price to compensate for the higher cost. In contrast, Red Friesians and crossbreds are associated with a price premium in most cases, as these are animals specialized in beef production. Crossbreds are particularly interesting for stockmen, as they exhibit a heterosis effect that enhances the fattening abilities over those of pure breeds. With the exception of 'finished cows', Red Friesians earn a price premium that varies from $12.69 \%$, for 'calves', to $3.70 \%$, for 'finished steers'. In turn, crossbreds show percent impacts that range between $0.82 \%$, for 'finished steers', to $4.11 \%$, for 'finished heifers', although the results for 'finished steers' and 'finished cows' are not significant and should be interpreted as not differing from fattening a Hereford cow, the reference animal.

In relation to seasonality, the first two quarters of the year are associated with price reductions

Table 5. Percent impact and marginal prices associated with the attributes of beef cattle under investigation.

\begin{tabular}{|c|c|c|c|c|c|c|}
\hline & \multicolumn{2}{|c|}{ Finished steers } & \multicolumn{2}{|c|}{ Finished heifers } & \multicolumn{2}{|c|}{ Finished cows } \\
\hline & $\begin{array}{c}\text { Percent impact } \\
(\%)\end{array}$ & $\begin{array}{l}\text { Marginal price } \\
\qquad\left(\$ \mathrm{~kg}^{-1}\right)\end{array}$ & $\begin{array}{c}\text { Percent } \\
\text { impact } \\
(\%)\end{array}$ & $\begin{array}{l}\text { Marginal price } \\
\qquad\left(\$ \mathrm{~kg}^{-1}\right)\end{array}$ & $\begin{array}{c}\text { Percent } \\
\text { impact } \\
(\%)\end{array}$ & $\begin{array}{l}\text { Marginal price } \\
\quad\left(\$ \mathrm{~kg}^{-1}\right)\end{array}$ \\
\hline Head & 0.09 & 0.54 & 0.20 & 1.06 & 0.62 & 3.77 \\
\hline Weight & 0.05 & 0.31 & 0.06 & 0.32 & 0.01 & 0.04 \\
\hline Condition & 10.88 & 63.23 & 16.85 & 90.92 & 21.83 & 133.05 \\
\hline Year 07 & -5.23 & -30.40 & 1.28 & 6.92 & 6.68 & 40.74 \\
\hline Year 08 & 6.89 & 40.05 & 12.20 & 65.85 & 11.29 & 68.79 \\
\hline Quarter 1 & -9.66 & -56.13 & -9.08 & -48.98 & -10.00 & -60.92 \\
\hline Quarter 2 & -6.51 & -37.85 & -10.45 & -56.40 & -11.35 & -69.17 \\
\hline Quarter 3 & 1.19 & 6.94 & 5.77 & 31.12 & 7.85 & 47.83 \\
\hline Reds & 3.70 & 21.47 & 5.10 & 27.51 & 0.41 & 2.47 \\
\hline HFriesians & -14.58 & -84.69 & -34.17 & -184.41 & -20.83 & -126.95 \\
\hline Crossbreds & 0.82 & 4.76 & 4.11 & 22.19 & 2.47 & 15.06 \\
\hline
\end{tabular}


and the Third Quarter with a price premium, compared to the fourth quarter.

The price reductions observed during the First Quarter range from $9.08 \%$ to $10.00 \%$, in the Second Quarter between 6.51\% and $11.35 \%$, whereas the Third Quarter is associated with a premium that ranges from $1.19 \%$ to $7.85 \%$, depending on the type of animal. The first two quarters of the year correspond to seasons when farms attempt to reduce their stocking rates in preparation for winter and, hence, sell their excess cattle in stockyards, thus depressing prices. In contrast, the Third Quarter corresponds to spring, when pastures are abundant and cattlemen are engaged in the fattening process; they tend to buy instead of sell cattle, to take advantage of their pasture resources. Hence, the two final quarters of the year are the best for reaching the market, and the third quarter should be preferred to the fourth.

Regarding business cycles, some of the results are not significant, but on the whole they suggest price improvements in the years 2007 and 2008 with regard to 2006 . Thus, it can be inferred that the study was carried out during the increasing phase of the cattle cycle.

The effect of adding an extra kilogram to a finished animal is negligible, adding a price premium equivalent to $0.05 \%$, for 'finished steers', and $0.06 \%$, for 'finished heifers', whereas in 'finished cows', this premium is statistically equal to zero. These results show that what the market demands is an animal that has reached the weight necessary to be classified as 'finished', and any weight over and above this target weight has little significance. As stated earlier, the finishing weight varies by breed, and thus a Holstein Friesian steer weighing 450 kilograms is classified as 'lean' while a Hereford at the same weight is considered 'finished'. Finally, slightly higher but still low values are obtained for 'lot size', showing that cattle traders value marginally purchasing their cattle requirements in only a few transactions.

The objective of this study was to assess the effect on the final price of live cattle of the observable characteristics commonly published in auction catalogues. It was found that the most influential variables on the price of beef cattle are, in decreasing order, 'condition', 'breed', 'quarter of sale' and 'year', which are followed far behind by 'lot size' and 'average weight'.

This study showed that the market pays a premium for Red Friesians, Crossbreds and Herefords. In contrast and as expected, it punishes the price of Holstein Friesians, as this breed is not appropriate for beef production. Additionally, the prices show a clear seasonality as in the last two quarters of the year, higher prices are paid than during the first two, and the third quarter is preferable to the fourth.

Finally, the average lot weight and the lot size are variables with very little influence, emphasizing the fact that cattle traders do not pay based on weight but on corporal condition, which varies with the different breeds; ultimately, the price paid by the market is associated with the animals' finished weight.

\section{Resumen}

J.L. Troncoso, A. Engler, P. Manríquez y A. Valdivia. 2012. Factores que influyen en el precio del ganado en remates: El caso de la feria de Melipilla (Chile). Cien. Inv. Agr. 39(1): 37-45. El objetivo de este estudio es evaluar la influencia sobre el precio de características observables en el ganado en pié. Estas características son aquellas que normalmente se publican en los catálogos de los remates, como son: peso promedio del lote, tamaño del lote, edad, raza y condición corporal. También se evaluó la influencia de la estacionalidad y del ciclo ganadero, en el precio. Usando datos de El Tattersall S.A se 
ajustó una función hedónica de precios. Los resultados mostraron que las variables que más influyen en el precio son, en orden decreciente: 'condición corporal', 'raza', 'trimestre en que se hace la venta' y 'año'; en mucho menor escala, también influyen 'tamaño del lote' y 'peso promedio del lote'. El mercado paga una prima por Overos Colorados, híbridos y Hereford y también castiga el precio del ganado Holstein Friesian. Los precios son más altos en últimos dos trimestres del año respecto de los dos primeros, y el Tercer Trimestre paga mejores precios que el Cuarto. El peso promedio y el tamaño del lote tienen muy poca influencia sobre el precio.

Palabras clave: Función hedónica de precios, impacto porcentual en el precio, precio marginal.

\section{References}

Ahmandi-Esfahani, F.Z., and R.G. Stanmore, 1997. Export demand for attributes of Australian wheat in Asia and the Middle East. Food Policy 22: 145-154.

Barham, B.L., and T.R. Troxel. 2007. Factors affecting the selling price of feeder cattle sold at Arkansas livestock auctions in 2005. J. Anim. Sci. 85:3434-3441.

Buccola, S., and Y. Iizuka. 1997. Hedonic cost models and the pricing of milk components. American Journal Agricultural Economics 79: 452-462.

Bulut, H., and J.D. Lawrence. 2007. The value of third-party certification of preconditioning claims at Iowa feeder cattle auctions. Journal of Agricultural and Applied Economics 39: 625-640.

Coatney, K.L., Menkhaus, D.J., and J.D. Schmitz. 1996. Feeder cattle price determinants: A hedonic system of equations approach. Review of Agricultural Economics 18:193-211.

Combris, P., S. Lecocq, and M. Visser. 2000. Estimation of a hedonic price equation for Burgundy wine. Applied Economics 32: 961-967.

Correia de Sousa, C. 2005. Evolução e sazonalidade dos preços e da relação de troca do boi gordo e do bezerro no estado de São Paulo. Informações Econômicas 3(10): 32-41.

Donnell, J.D. 2007. Age and source verified preconditioned feeder cattle: costs and value. Master of Science thesis, Oklahoma State University. 120 pp.

Fielder, L.L., and A. Martinez. 1974. Weight-price relationships for calves, steers and heifers marketed through Louisiana auctions. Baton Rouge,
U.S.A. Research Report, Department of Agricultural Economics and Agribusiness, Louisiana State University. 43 pp.

Fox, D.G., R.R. Johnson, R.L. Preston, T.R. Dockerty, and E.W. Klosterman. 1972. Protein and energy utilization during compensatory growth in beef cattle. J. Anim. Sci. 34:310-320.

Gujarati, D. 2004. Econometría. Mc Graw Hill, Cuarta Edición. México 972 pp.

Halfman, B., J. Lehmkuhler, and T. Cox. 2009. Factors Affecting Wisconsin Feeder Calf Prices at Local Livestock Market. Journal of Extension 47(6): 1/8-7/8.

Halvorsen, R., and R. Palmquist. 1980. The interpretation of dummy variables in semi-logarithmic equations. American Economic Review 70:474-475.

Jones, S.D.M., M.A. Price, and R.T. Berg. 1978. The Influence of breed and sex on beef production. Agriculture and Forestry Bulletin, University of Alberta, Special Issue: 18-21.

Kennedy, P.E. 1981. Estimation with correctly interpreted dummy variables in semi-logarithmic equations. American Economic Review 71:801.

Lin, B.-H., and H. Mori. 1991. Implicit value of beef carcass characteristics in Japan: Implications for the U.S. beef export industry. Agribusiness 2(7): 101-114.

Melo, O., J.E. Buzeta, and M.B. Marshall. 2005. determinantes del precio del vino en el mercado chileno: un estudio de precios hedónicos. Economía Agraria 9: 58-73.

Nerlove, M. 1995. Hedonic price functions and the measurement of preferences: The case of Swedish wine consumers. European Economic Review 39: 1697-1716. 
Oczkowski, E. 1994. A hedonic price function for Australian premium table wine. Australian Journal of Agricultural Economics 38: 93-110.

Rosen, S. 1974. Hedonic prices and implicit markets: product differentiation in pure competition. Journal Political Economy 82:34-55.

Schamel, G., and K. Anderson. 2001. Wine quality and varietal, regional and winery reputations: Hedonic prices for Australia and New Zealand. Paper presented at the CIES Wine Economics Workshop of the Australian Wine Industry Technical Conference. Workshop Paper No. 20, Centre for International Economic Studies (CIES), Adelaide University, Australia. 16 pp.
Troncoso, J.L. and M. Aguirre. 2006. Price determinants of Chilean wines in the US market: a hedonic approach. Spanish Journal of Agricultural Research 4:124-129.

Troxel, T.R., and B.L. Barham. 2007. Comparing the 2000 and 2005 factors affecting the selling price of feeder cattle sold at Arkansas livestock auctions. J. Anim. Sci. 85:3425-3433.

Wahl, T.I., H. Shi, and R.C. Mittelhammer. 1995. A hedonic price analysis of quality characteristics of Japanese Wagyu beef. Agribusiness 1(11): 35-44. 
